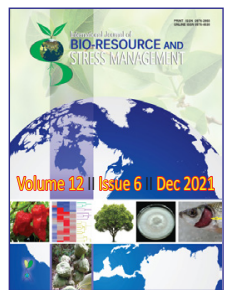

\title{
Identification of Polymorphism within Exon 8 of Bovine HSP90AA1 Gene using PCR-SSCP Technique
}

\author{
J. Sai Prasanna*, S. T. Viroji Rao, M. Gnana Prakash, Suresh Rathod, P. Kalyani and B. Rajith Reddy
}

College of Veterinary Science, P. V. Narsimha Rao Telangana Veterinary University, Rajendranagar, Hyderabad, Telangana State (500 030), India

foser

Open Access

Corresponding Author

J. Sai Prasanna

e-mail: drsaiprasannareddy@gmail.com

Citation: Prasanna et al., 2021. Identification of Polymorphism within Exon 8 of Bovine HSP90AA1 Gene using PCR-SSCP Technique. International Journal of Bio-resource and Stress Management 2021, 12(6), 611-616. HTTPS://DOI.ORG/10.23910/1.2021.2564

Copyright: (c) 2021 Prasanna et al. This is an open access article that permits unrestricted use, distribution and reproduction in any medium after the author(s) and source are credited.

Data Availability Statement: Legal restrictions are imposed on the public sharing of raw data. However, authors have full right to transfer or share the data in raw form upon request subject to either meeting the conditions of the original consents and the original research study. Further, access of data needs to meet whether the user complies with the ethical and legal obligations as data controllers to allow for secondary use of the data outside of the original study.

Conflict of interests: The authors have declared that no conflict of interest exists.
Article History

RECEIVED on $13^{\text {th }}$ August 2021 RECEIVED in revised form on $20^{\text {th }}$ November 2021 ACCEPTED in final form on $03^{\text {rd }}$ December 2021

\begin{abstract}
Heat shock proteins (HSPS) are a type of molecular chaperones that aid in the recovery of stressed cells and serve as a major system for intracellular self-defense. A study was conducted during the year 2018-19 at College of Veterinary Science Rajendranagar, Hyderabad, Telengana State, India to find polymorphisms in exon 8 of the bovine HSP9OAA1 gene in Sahiwal $(n=50)$ and crossbred $(n=50)$ cows. Blood samples were collected from the experimental animals and genomic DNA was isolated. Physiological parameters like body temperature and respiration rate for each animal were taken during the experimental period and the heat tolerance coefficient was calculated. The data on production and reproduction traits were obtained from the history sheets of the animals. To detect the polymorphism, a 539 bp fragment of the HSP90AA1 gene covering exon 8 was subjected to the Polymerase Chain Reaction-Single-Strand Conformation Polymorphism (PCR-SSCP) technique.The PCR-SSCP of exon 8 of HSP9OAA1 gene yielded two genotypic patterns $A A$ and $A B$ corresponding to two allelic variants with frequencies of $0.85,0.15,0.81$ and 0.19 in Sahiwal and crossbred cows, respectively. The PCRSSCP patterns obtained were correlated with the physiological, productive, and reproductive traits in both Sahiwal and crossbred cows. The association analysis of SSCP patterns of the exon 8 of HSP9OAA1 gene revealed non-significant effect in Sahiwal cows, although the $A B$ genotype had a significantly longer service period in crossbred cows.
\end{abstract}

Keywords: Crossbred cows, Exon 8, Heat stress, HSP90AA1, Polymorphisms, Sahiwal

\section{Introduction}

Heat shock proteins (HSPs) are molecular chaperones that assist cells in recovering from stress and providing cytoprotection, which protects them from further attack. They protect stressed cells by identifying nascent polypeptides, unstructured protein regions, and exposed hydrophobic amino acid stretches. Heat shock proteins are encoded by HSP genes. Though there are many HSP genes, thermo tolerance in livestock animals is primarily associated with the HSP7O and HSP9O genes. The most common and temperature-sensitive is HSP9O, which is thought to play an important role in environmental stress and thermal adaptation (Gade et al., 2010; Aritonang et al., 2017; Puteri et al., 2018). In summer, higher levels of expression of proteins of the HSP70 and HSP9O families have been observed in a variety of livestock species (Archana et al., 2017). Polymorphisms in the HSP90 genes have been associated to heat 
tolerance, milk production, fertility, and disease susceptibility in livestock (Shergojry et al., 2014a; Kumar et al., 2015; Bhat et al., 2016). They may be useful as candidate gene markers for identifying animals with enhanced climatic resistance, immunological response, and performance (Hassan et al., 2019).

Holstein Friesian is extensively used for crossbreeding in India (Wakchaure et al., 2015). Several crossbred populations with Friesian inheritance ranging from $35.93 \%$ to $93.75 \%$ were investigated and performance evaluated. It was observed that crossbreds with $62.5 \%$ of Friesian inheritance were found to be superior to all other crosses (Bhaduria and Katpatal, 2003, Lakshmi et al., 2010).

Sahiwal is among the best milch breeds of the Indian sub-continent (Nivsarkar et al., 2013), with an average lactation milk yield of $1880 \mathrm{~kg}$ (Verma et al., 2016). They are highly tolerant of tropical diseases and are known for their adaptability to heat stress. However, their number is fast dwindling due to indiscriminate crossbreeding and is resulting in the loss of unique heat stress genes due to genetic recombination (Singh, 2016). Therefore, there is an urgent need to characterize these unique genes in Sahiwal and other indigenous cattle breeds.

Although differences in thermo tolerance have been documented at the physiological and cellular level in both Bos indicus and Bos taurus cattle (Collier et al., 2006; Chaiyabutr et al., 2008; Behl et al., 2010; Wilson and Crandall, 2010, and Dalcin et al., 2016), data on polymorphism of HSP genes in Sahiwal cattle and Holstein Friesian crossbreds is limited. Only a few reports on the relationship of HSP gene polymorphism with heat tolerance in Tharparkar cattle (Bhat et al., 2016), Deoni cattle (Kerekoppa et al., 2015), Jersey crossbred cows (Sailo et al., 2015a), and Holstein cows (Sailo et al., 2015b; Li et al., 2011) have been published.

The chaperone HSP9O is one of the most abundant proteins in eukaryotic cells, comprising 1-2\% of cellular proteins under non-stress conditions (Young et al., 2001). There are two major cytoplasmic HSP90 isoforms, the inducible form (HSP9OAA1/ $H S P 90 \alpha$ ) and the constitutive form (HSP90AB1/HSP90ß), which have arisen by gene duplication (Chen et al., 2005).

HSP90AA1 gene is located on Bos taurus autosome 21 (BTA 21) and spans nearly 5368 bp comprising of 11 exons out of which the first exon does not translate. In the current study, polymorphisms in the exon 8 of the HSP9OAA1 gene and their associations with various physiological, production, and reproduction traits in Sahiwal and crossbred cows were investigated.

\section{Materials and Methods}

\subsection{Experimental animals}

A total of 50 Sahiwal cows were used in this study.

\subsection{Genomic DNA isolation}

Genomic DNA was extracted from blood samples of the experimental animals ( 50 Sahiwal cows maintained at the
Livestock Farm Complex, College of Veterinary Science Rajendranagar, and 50 crossbred cows (Holstein Friesian $X$ Sahiwal) maintained at the Military Dairy Farm, Secunderabad) using the standard phenol-chloroform extraction method as described by Green and Sambrook (2012), with minor modifications. The purity of the genomic DNA samples was determined by measuring the optical densities (OD) at $260 \mathrm{~nm}$ and $280 \mathrm{~nm}$ against a blank using Nanodrop (Thermo Fisher Scientific) and storing them at $-20^{\circ} \mathrm{C}$ until further use.

\subsection{Physiological parameters}

The physiological parameters, respiration rate (RR), and rectal temperature (RT) of each animal in the current study were recorded twice daily for 30 days in each of the three seasons, i.e during May (2018) for summer, August (2018) for rainy, and from mid-December (2018) to mid-January (2019) for winter season, respectively, and the average was taken as the final reading for association analysis in the study. The physiological parameters were recorded at $8 \mathrm{AM}$ and $2 \mathrm{PM}$. The Heat Tolerance Coefficient (HTC) was calculated for each animal based on respiration rate and rectal temperature using the formula given by Benezra (1954).

\subsection{Production and reproduction traits}

Data on each animal about different aspects like Animal no., Sire no., Dam no., Date of birth, Date of calving, Lactation length and Lactation milk yield, etc., were collected from the history sheet/daily farm registers maintained at the concerned farms. The various production and reproduction traits like Total Lactation Milk Yield (TLMY), Peak Yield (PY), Lactation length (LL), Service Period (SP), Dry Period (DP) and Calving Interval (Cl) were calculated from the available data in both Sahiwal and crossbred cows.

\subsection{PCR primers and amplifications}

Primers (procured from BioServe Biotechnologies Pvt Ltd, Hyderabad) specific for the desired fragment (539bp) of the HSP90AA1 gene covering exon 8 region were used to amplify the targeted region. The details of primer sequences, length of the primer (bp), melting temperature $(\mathrm{Tm})$ are presented in Table 1.

The PCR reaction mixture was prepared for a $12.5 \mu \mathrm{l}$ reactionusing the components as given in Table 2 and the PCR cycling conditions used are given in Table 3.

The PCR products were detected by electrophoresis on $2 \%$

Table 1: Sequence of primers, their respective number of bases and melting temperature of bovine HSP gene fragment

\begin{tabular}{llcc}
\hline $\begin{array}{l}\text { Gene } \\
\text { fragment }\end{array}$ & Sequence $\left(5^{\prime}-3^{\prime}\right)$ & $\begin{array}{c}\text { Length of } \\
\text { the } \\
\text { primer }(\mathrm{bp})\end{array}$ & $\begin{array}{c}\text { Melting } \\
\text { Tempera- } \\
\text { ture }\left({ }^{\circ} \mathrm{C}\right)\end{array}$ \\
\hline $\begin{array}{l}\text { Exon 8 } \\
539 \mathrm{bp}\end{array}$ & $\begin{array}{l}\text { CCCATGGGAACAGTT- } \\
\text { GAGTG }\end{array}$ & 20 & 54 \\
& $\mathrm{R}$ & $\begin{array}{l}\text { GCTTTAAGCTCCTTT- } \\
\text { TAAGTTCG }\end{array}$ & 23 \\
\hline
\end{tabular}

F: Forward; R: Reverse 


\begin{tabular}{lc}
\hline \multicolumn{2}{l}{ Table 2: Components of PCR reaction mixture } \\
\hline Components & Volume $(\mu \mathrm{l})$ \\
\hline Taq polymerase $\left(5\right.$ units $\left.\mathrm{f}^{-1}\right)$ & 0.125 \\
dNTPs $(10 \mathrm{mM})$ & 0.8 \\
Primer-forward $(10 \mathrm{pM})$ & 1.0 \\
Primer-reverse $(10 \mathrm{pM})$ & 1.0 \\
10x Taq buffer & 2.5 \\
Nuclease-free water $(\mathrm{NFW})$ & 6.075 \\
Template DNA & 1.0 \\
Total & 12.5 \\
\hline
\end{tabular}

Table 3: Conditions of PCR reaction

\begin{tabular}{lcc}
\hline Steps & Temperature $\left({ }^{\circ} \mathrm{C}\right)$ & Time \\
\hline Initial denaturation & 95 & $5 \mathrm{~min}$ \\
Cyclic denaturation & 95 & $30 \mathrm{sec}$ \\
Primer annealing & 51 & $45 \mathrm{sec}$ \\
Cyclic extension & 72 & $30 \mathrm{sec}$ \\
Steps 2 to 4 were repeated for $35 \mathrm{cycles}$ & \\
\hline Final extension & 72 & $10 \mathrm{~min}$ \\
Hold & 4 & Forever \\
\hline
\end{tabular}

agarose gel stained with ethidium bromide.

\subsection{Single strand conformation polymorphism (SSCP)}

Polymorphism in exon 8 of HSP9OAA1 gene was screened using the single-strand conformation polymorphism (SSCP) technique using the amplified PCR products. The variants were identified basing on the band pattern observed in the SSCP gels after silver staining (Bassam and Gresshoff, 2007). The most common band pattern identified was named as A. If there are more bands, in addition to the common bands, they were marked as B, C, etc., depending on the band pattern.

\subsection{Genotype and allele frequencies}

Genotype frequencies for variant genotypes were calculated using the formula:

Genotypefrequency $=$ (No.ofanimals with specific genotype ( $A A, A B$ or $B B$ ))/Total No.ofanimals

Allele frequencies were calculated as follows:

Where,

$\mathrm{AA}$ and $\mathrm{BB}=$ Genotype frequencies of homozygotes

$A B=$ Genotype frequency of heterozygote

$A$ and $B=A l l e l e$ frequencies

\subsection{Association analysis}

Statistical analysis was done to study the association of each SSCP genotype on physiological, production, and reproduction traits in Sahiwal and crossbred cows. Data on physiological traits was corrected for season effect and used for association analysis. The univariate GLM model of SPSS 25 was used to perform the analysis according to the following statistical model:

$Y_{i j k}=\mu+G_{i}+P_{j}+e_{i j k}$

Where, $Y_{\mathrm{ijk}}=$ Dependent variable (respiration rate, rectal temperature, heat tolerance coefficient, total lactation milk yield, peak yield, lactation length, gestation period, service period, dry period and calving interval)

$\mu=$ Overall mean,

$\mathrm{G}=$ Effect of $\mathrm{i}^{\text {th }}$ SSCP genotype $(\mathrm{i}=1 \ldots \mathrm{n})$

$P j=E f f e c t$ of $j^{\text {th }}$ parity of the animal at the time of blood collection $(j=1 \ldots n)$

$\mathrm{e}_{\mathrm{ijk}}=$ Random error assumed to be distributed normally and independently with mean zero and variance $\sigma^{2}$.

Significant differences between the means of different genotypes and parities were tested by Duncan's Multiple Range Test (DMRT). Values were considered significant at $p \leq 0.05$ and presented as means \pm standard errors.

\section{Results and Discussion}

\subsection{PCR-SSCP of exon 8 of HSP9OAA1 gene}

The PCR reactions were set for all the animals (50 each of Sahiwal and crossbreds) with species-specific primers available in the literature for the amplification of exon 8 of HSP9OAA1 gene. Amplification of desired size was noticed in all the tested samples. The representative figures showing the PCR amplified products of exon 8 of HSP9OAA1 gene, showing the size of 539 bp are presented in Figure 1, while the PCR-SSCP polyacrylamide gel imageis presented in Figure 2.

PCR-SSCP of exon 8 (539 bp)of the HSP9OAA1 gene revealed two different SSCP patterns AA and AB in both Sahiwal and crossbred cows. Consequently, at this locus two alleles namely A and B with allelic frequency of 0.85 and 0.15 , respectively in Sahiwal and 0.81 and 0.19 , respectively in crossbred cowswere present. The frequencies of AA and BB genotypes were estimated to be 0.70 and 0.30 in Sahiwal and 0.62 and

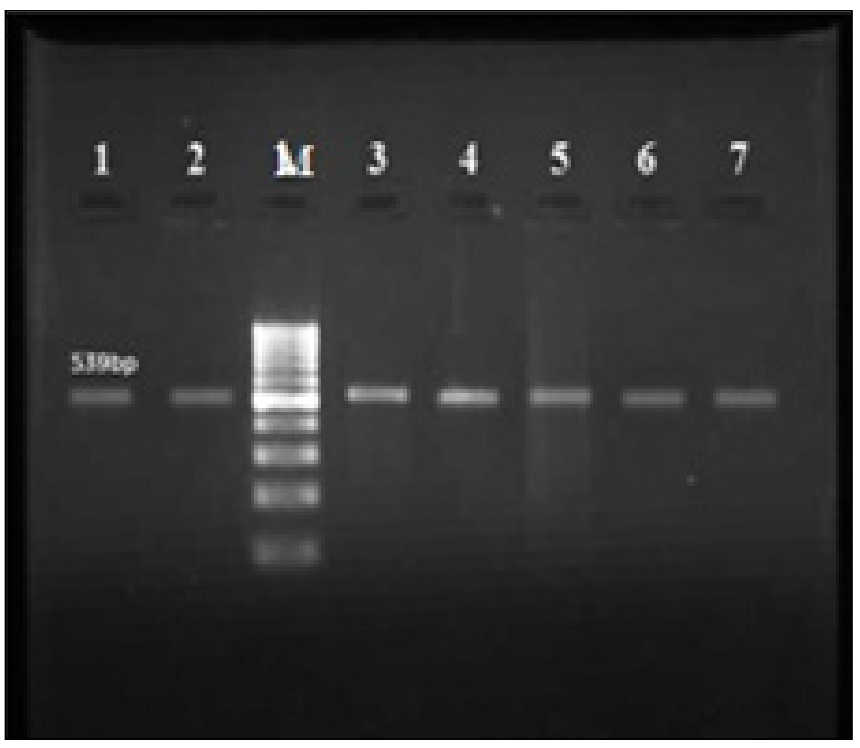

Figure 1: Agarose gel electrophoresis image showing PCR amplified product (539bp) of HSP9OAA1 gene 


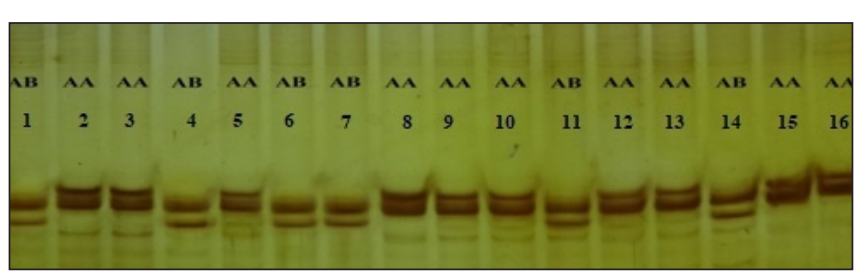

Figure 2: Polyacrylamide gel electrophoresis showing PCRSSCP patterns for 539bp fragment of HSP90AA1 gene. Lane 1-8 Sahiwal; Lane 9-16 Crossbred cows

0.38 in crossbred cows, respectively. However, Shergojry et al. (2014a) analyzed the polymorphism in the same region (exon 8) of HSP9OAA1 gene using the PCR-SSCP technique in Deoni cattle and revealed three unique SSCP genotypes with frequencies of $0.250,0.639$ and 0.111 respectively. Shergojry et al. (2014b) also found two SSCP patterns in exon 9 region ofHSPAA1 gene with frequencies of 0.153 and 0.847 and two PCR-SSCP patterns in exon 10 with frequencies 0.236 and 0.764 respectively in Deoni cows. Also Badri et al. (2018) identified five single nucleotide polymorphisms in Chinese Holstein lactating cows: one in the promoter, three in the coding region, and one in 3'-UTR region of HSP9OAA1 gene.

\subsection{Association analysis of HSP9OAA1 gene polymorphism}

The means obtained from the analysis of variance for the effect of exon 8 of HSP9OAA1 genotypes on the physiological, production and reproduction traits in Sahiwal and crossbred cows are presented in Tables 4, 5 and 6 respectively.

\begin{tabular}{|c|c|c|c|c|c|c|c|c|c|c|c|c|c|c|}
\hline \multirow[t]{4}{*}{ Effect } & \multicolumn{7}{|c|}{ Sahiwal } & \multicolumn{7}{|c|}{ Crossbreds } \\
\hline & \multirow[t]{2}{*}{$\mathrm{n}$} & \multicolumn{2}{|c|}{$\mathrm{RR}$} & \multicolumn{2}{|c|}{$\mathrm{RT}\left({ }^{\circ} \mathrm{C}\right)$} & \multicolumn{2}{|c|}{ HTC } & \multirow[t]{2}{*}{$n$} & \multicolumn{2}{|c|}{$\mathrm{RR}$} & \multicolumn{2}{|c|}{$\mathrm{RT}\left({ }^{\circ} \mathrm{C}\right)$} & \multicolumn{2}{|c|}{ HTC } \\
\hline & & Mean & SE & Mean & SE & Mean & SE & & Mean & SE & Mean & SE & Mean & SE \\
\hline & 50 & 23.97 & 0.24 & 38.28 & 0.03 & 2.04 & 0.01 & 50 & 30.95 & 0.38 & 38.57 & 0.04 & 2.35 & 0.02 \\
\hline \multicolumn{15}{|c|}{ Genotype } \\
\hline AA & 35 & 24.38 & 0.25 & 38.30 & 0.03 & 2.06 & 0.01 & 31 & 31.27 & 0.45 & 38.57 & 0.04 & 2.37 & 0.02 \\
\hline$A B$ & 15 & 23.56 & 0.45 & 38.25 & 0.05 & 2.02 & 0.02 & 19 & 30.63 & 0.58 & 38.57 & 0.06 & 2.34 & 0.03 \\
\hline \multicolumn{15}{|l|}{ Parity } \\
\hline 1 & 13 & 24.80 & 0.40 & 38.36 & 0.04 & 2.08 & 0.02 & 5 & 31.33 & 1.26 & 38.66 & 0.12 & 2.37 & 0.06 \\
\hline 2 & 11 & 23.89 & 0.50 & 38.27 & 0.05 & 2.03 & 0.02 & 7 & 30.86 & 0.97 & 38.50 & 0.09 & 2.35 & 0.04 \\
\hline 3 & 18 & 23.72 & 0.34 & 38.24 & 0.04 & 2.03 & 0.01 & 12 & 30.90 & 0.70 & 38.53 & 0.07 & 2.35 & 0.03 \\
\hline 4 & 8 & 23.47 & 0.56 & 38.24 & 0.06 & 2.01 & 0.02 & 9 & 31.23 & 0.82 & 38.65 & 0.08 & 2.37 & 0.04 \\
\hline 5 & - & - & - & - & - & - & - & 9 & 30.42 & 0.79 & 38.64 & 0.07 & 2.33 & 0.03 \\
\hline 6 & - & - & - & - & - & - & - & 8 & 29.37 & 0.82 & 38.60 & 0.08 & 2.29 & 0.04 \\
\hline
\end{tabular}

Table 5: Means of HSP9OAA1 exon 8 genotypes and parity effects for production traits in Sahiwal and crossbred cows

\begin{tabular}{|c|c|c|c|c|c|c|c|c|c|c|c|c|c|c|}
\hline \multirow[t]{3}{*}{ Effect } & \multicolumn{7}{|c|}{ Sahiwal } & \multicolumn{7}{|c|}{ Crossbreds } \\
\hline & \multirow[t]{2}{*}{$\mathrm{n}$} & \multicolumn{2}{|c|}{ TLMY } & \multicolumn{2}{|c|}{ PY } & \multicolumn{2}{|c|}{ LL } & \multirow[t]{2}{*}{$\mathrm{n}$} & \multicolumn{2}{|c|}{ TLMY } & \multicolumn{2}{|c|}{ PY } & \multicolumn{2}{|c|}{ LL } \\
\hline & & Mean & SE & Mean & SE & Mean & SE & & Mean & SE & Mean & SE & Mean & SE \\
\hline & 50 & 1707.48 & 123.80 & 10.03 & 0.47 & 268.94 & 15.56 & 50 & 2837.11 & 97.55 & 13.64 & 0.50 & 328.48 & 2.73 \\
\hline \multicolumn{15}{|c|}{ Genotype } \\
\hline $\mathrm{AA}$ & 35 & 1841.91 & 125.71 & 10.19 & 0.47 & 273.94 & 15.80 & 31 & 2974.37 & 114.64 & 14.09 & 0.59 & 331.67 & 3.20 \\
\hline$A B$ & 15 & 1573.05 & 227.87 & 9.86 & 0.86 & 263.94 & 28.65 & 19 & 2699.86 & 148.53 & 13.20 & 0.76 & 325.28 & 4.15 \\
\hline \multicolumn{15}{|l|}{ Parity } \\
\hline 1 & 13 & 2017.72 & 203.34 & 10.63 & 0.77 & 317.84 & 25.56 & 5 & $2479.25 c$ & 319.67 & 12.85 & 1.65 & $333.60^{\mathrm{ab}}$ & 8.94 \\
\hline 2 & 11 & 1470.35 & 253.30 & 9.38 & 0.95 & 237.73 & 31.85 & 7 & $3392.85 a$ & 247.18 & 16.29 & 1.27 & $337.64^{a}$ & 6.91 \\
\hline 3 & 18 & 1923.69 & 173.04 & 11.31 & 0.65 & 284.06 & 21.75 & 12 & $3285.80 a$ & 177.99 & 14.42 & 0.92 & $322.82^{c}$ & 4.98 \\
\hline 4 & 8 & 1418.17 & 285.08 & 8.80 & 1.07 & 236.13 & 35.84 & 9 & $3456.25 a$ & 208.75 & 16.79 & 1.07 & $321.69^{c}$ & 5.83 \\
\hline 5 & - & - & - & - & - & - & - & 9 & $3364.50 a$ & 200.01 & 14.90 & 1.03 & $314.65^{d}$ & 5.59 \\
\hline 6 & - & - & - & - & - & - & - & 8 & $3045.61 b$ & 208.75 & 14.21 & 1.07 & $330.74^{b}$ & 5.83 \\
\hline
\end{tabular}

Means with similar superscripts in a column do not differ significantly $(p \leq 0.05)$ 


\begin{tabular}{|c|c|c|c|c|c|c|c|c|c|c|c|c|c|c|}
\hline \multirow[t]{4}{*}{ Overall } & \multicolumn{7}{|c|}{ Sahiwal } & \multicolumn{7}{|c|}{ Crossbreds } \\
\hline & \multirow[t]{2}{*}{$n$} & \multicolumn{2}{|c|}{ SP (days) } & \multicolumn{2}{|c|}{ DP (days) } & \multicolumn{2}{|c|}{$\mathrm{Cl}$ (days) } & \multirow[t]{2}{*}{$\mathrm{n}$} & \multicolumn{2}{|c|}{ SP (days) } & \multicolumn{2}{|c|}{ DP (days) } & \multicolumn{2}{|c|}{$\mathrm{Cl}$ (days) } \\
\hline & & Mean & SE & Mean & SE & Mean & SE & & Mean & SE & Mean & SE & Mean & SE \\
\hline & 44 & 150.73 & 10.41 & 135.46 & 8.74 & 432.90 & 8.76 & 46 & 203.74 & 9.23 & 158.00 & 7.44 & 417.267 & 8.119 \\
\hline \multicolumn{15}{|c|}{ Genotype } \\
\hline AA & 32 & 152.56 & 9.80 & 144.48 & 8.23 & 439.20 & 8.25 & 30 & $183.21 b$ & 10.68 & 150.29 & 8.61 & 409.163 & 9.393 \\
\hline$A B$ & 12 & 148.91 & 19.63 & 126.45 & 16.49 & 426.60 & 16.52 & 16 & $224.27 a$ & 14.70 & 165.71 & 11.85 & 425.372 & 12.932 \\
\hline \multicolumn{15}{|l|}{ Parity } \\
\hline 1 & 13 & 192.78 & 15.11 & 147.70 & 12.69 & 466.50 & 12.71 & 5 & 198.18 & 29.45 & 162.57 & 23.74 & 450.04 & 25.90 \\
\hline 2 & 11 & 144.36 & 19.47 & 159.53 & 16.35 & 413.70 & 16.38 & 7 & 247.49 & 22.77 & 136.06 & 18.35 & 429.38 & 20.02 \\
\hline 3 & 14 & 138.96 & 15.40 & 121.63 & 12.93 & 441.04 & 12.96 & 11 & 204.84 & 17.18 & 173.13 & 13.85 & 409.59 & 15.18 \\
\hline 4 & 6 & 126.84 & 24.18 & 112.98 & 20.30 & 410.36 & 20.35 & 7 & 192.18 & 20.93 & 165.40 & 16.87 & 423.87 & 18.41 \\
\hline 5 & - & - & - & - & - & - & - & 8 & 193.52 & 20.22 & 172.08 & 16.30 & 417.36 & 17.78 \\
\hline 6 & - & - & - & - & - & - & - & 8 & 186.83 & 20.72 & 150.83 & 16.70 & 416.50 & 18.22 \\
\hline
\end{tabular}

Means with similar superscripts in a column do not differ significantly $(p \leq 0.05)$

\subsubsection{Associationwith physiological traits}

The SSCP genotypes of exon 8 of the HSP9OAA1 gene obtained in the present study had no significant effect on the physiological parameters studied in both Sahiwal and crossbred cows. However, Kumar et al. (2015) found that other regions of HSPAA1 gene were polymorphic and that AA genotype had lower heat tolerance coefficient as compared to AG and GG genotypes in Sahiwal cows and GG genotype had lower mean respiration rate, rectal temperature and HTC in Karan Fries cows (Kumar et al., 2016)

\subsection{Association with production traits}

The effect of genotype was found to be non significant in both genetic groups, while parity significantly influenced the total lactation milk yield and lactation length in crossbred cows. No studies were available to compare the results, with respect to the PCR- SSCP genotypes.

\subsection{Association analysis with reproduction traits}

The differences obtained in various traits due to different genotypes of exon 8 of the HSP9OAA1 gene were not statistically significant in Sahiwal cows, whereas in crossbred cows the effect of genotype was significant only on service period with $A B$ genotype having longer service period. The results could not be compared as there were no studies pertaining to the association of HSP9O gene polymorphisms in indigenous or crossbred cattle breeds.

\section{Conclusion}

The SSCP patterns obtained in the current study for various fragments of HSP genes and their association analysis with physiological and production parameters revealed no significant differences between genotypes, implying that a larger sample size with a broad genetic base may be required to elucidate the polymorphism association.

\section{References}

Archana, P.R., Aleena, J., Pragna, P., Vidya, M.K., Abdul Niyas, P.A., Bagath, M., Krishnan, G., Manimaran, A., Beena, V., Kurien, E.K., Sejian, V., Bhatta, R., 2017. Role of heat shock proteins in livestock adaptation to heat stress. Journal of Dairy, Veterinary and Animal Research 5(1), 13-19.

Aritonang, S.B., Yuniati, R., Abinawanto, Imron, M., Bowolaksono, A., 2017. Effect of thermal stress on HSP90 expression of Bali cattle in Barru district, South Sulawesi. AIP Conference Proceedings 1862, 030104. https://doi. org/10.1063/1.4991208

Badri, T.M., Chen, K.L., Alsiddig, M.A., Li, L., Cai, Y., Wang, G.L., 2018. Genetic polymorphism in Hsp90AA1 gene is associated with the thermo tolerance in Chinese Holstein cows. Cell Stress Chaperones 23(4), 639-651

Bassam, B.J., Gresshoff, P.M., 2007. Silver staining DNA in polyacrylamide gels. Nature Protocols. 2(11), 2649-2654.

Behl, R., Behl, J., Joshi, B.K., 2010. Heat tolerance mechanismin cattle-statusin zebu cattle: A review. Journal of AnimalScience 80(9), 891-897.

Benezra, M.V., 1954. A new index for measuring the adaptability of cattle to tropical conditions. Journal of Animal Science 13, 1015

Bhadauria, S.S., Katpatal, B.G., 2003. Effect of genetic and nongenetic factors on 300-days milk yield of first lactation in Friesian $\times$ Sahiwal crosses. Indian Veterinary Journal 80, 1251-1254

Bhat, S., Kumar, P., Kashyap, N., Deshmukh, B., Dige, M.S., Bhushan, B., Chauhan, A., Kumar, A., Singh, G., 2016. 
Effect of heat shock protein 70 polymorphism on thermotolerance in Tharparkar cattle. Veterinary World 92, 113-117.

Chaiyabutr, N., Chanpongsang, S., Suadsong, S., 2008. Effects of evaporative cooling on the regulation of body water and milk production in crossbred Holstein cattle in a tropical environment. International Journal of Biometerology 52, 575-585.

Chen, B., Piel, P.H., Gui, E.B., Monteiro, A., 2005. The HSP90 family of genes in the human genome: Insights into their divergence and evolution. Genomics 86(6), 627-637

Collier, R.J., Dahl, G.E., Van, Baale, M.J., 2006. Major advances with environmental effects on dairy cattle. Journal of Dairy science $89,1244-1253$.

Dalcin, V., Fischer, V., Daltro, D., Alfonzo, M., Priscila, E., Marcelo, S., Giovani, K., Marcos, S., Concepta, M., 2016. Physiological parameters for thermal stress in dairy cattle. Revista Brasileira de Zootecnia 45, 458-465

Gade, N., Mahapatra, R.K., Sonawane, A., Singh, V.K., Doreswamy, R., Saini, M., 2010. Molecular characterization of heat shock protein 70-1 gene of goat (Capra hircus). Molecular Biology International. Article ID 108429

Green, M.R., Sambrook, J., 2012. Molecular Cloning: A laboratory manual. New York, USA: Cold Spring

Hassan, F., Nawaz, A., Rehman, M.S., Ali, M.A., Dilshad, S.M.R., Yang, C., 2019. Prospects of HSP70 as a genetic marker for thermo-tolerance and immuno-modulation in animals under climate change scenario. Animal Nutrition 54340-54350.

Kerekoppa, R., Rao, A., Basavaraju, M., Geetha, G., Krishnamurthy, L., Narasimha, L., Das, D., Mukund, K., 2015. Molecular characterization of the HSPA1A gene by single-strand conformation polymorphism and sequence analysis in Holstein-Friesian crossbred and Deoni cattle raised in India. Turkish Journal of Veterinary and Animal Sciences 39, 128-133.

Kumar, R., Gupta, I.D., Verma, A., Singh, S.V., Verma, N., Vineeth, M.R., Magotra, A., Das, R., 2016. Novel SNP identification in exon 3 of HSP90AA1 gene and their association with heat tolerance traits in Karan Fries (Bostaurus $\times$ Bosindicus) cows under tropical climatic condition. Tropical Animal Health and Production 48(4), 735-740

Kumar, R., Gupta, I.D., Verma, A., Verma, N., Nishant, Vineeth, M.R., 2015. Single nucleotide polymorphisms in Heat Shock Protein (HSP) 90AA1 gene and their association with heat tolerance traits in Sahiwal cows. Indian Journal of Animal Research 51, 64-69.

Lakshmi, B.S., Gupta, B.R., Prakash, M.G., Sudhakar, K., Sharma, S., 2010. Genetic analysis of production performance of Frieswal cows. Tamilnadu Journal of Veterinary and
Animal Sciences 65, 215-222

Li, Q., Han, J., Du, F., Ju, Z., Huang, Z., Wang, J., Li, R., Wang, C., Zhong, J., 2011. Novel SNPs in HSP70A1A gene and the association of polymorphisms with thermo tolerance traits and tissue specific expression in Chinese Holstein cattle. Molecular Biology Reports. 38, 2657-63

Nivsarkar, A.E., Vij, P.K., Tantia, M.S., 2013. Animal genetic resources of India: Cattle and Buffalo. ICAR, India, 382

Puteri, S.A., Aritonang, S.B., Nussa, H.T., Rahmani, A.F., Bowolaksono, A., Lestari, R., 2018. The profile of HSP9O gene expression of Bali cattle to heat stress in West Sumbawa, West Nusa Tenggara. AIP Conference Proceedings 2023, 020138. https://doi. org/10.1063/1.5064135

Sailo, L., Gupta, I.D., Verma, A., Chaudhari, M.V., Das, R., Upadhyay, R.C., Goswami, J., 2015b. Single nucleotide polymorphisms in HSP90AB1 gene and its association with thermo tolerance in Jersey crossbred cows. Animal Science Reporter 9, 43-49

Sailo, L., Gupta, I.D., Verma, A., Das, R., Chaudhari, M.V., 2015a. Association of single nucleotide polymorphism of HSP90ab1 gene with thermotolerance and milk yield in Sahiwal cows. African Journal of Biochemistry Research 98, 99-103

Shergojry, S.A., Ramesha, K.P., Aarif, O., Mir, N.A., 2014b. Genetic polymorphisms within exon 8, 9 and 10 of heat shock protein HSP 90AA1 in Deoni cattle. Animal Science Reporter 8(1), 26-30

Shergojry, S.A., Ramesha, K.P., Mir, N.A., Aarif, O., 2014a. Nucleotide sequence polymorphism within Exon 8 of Heat Shock Protein HSP 90AA1 gene and its association with milk production traits in Deoni cows. Indian Journal of Animal Research 48(5), 408-12

Singh, C.V., 2016. Cross-breeding in Cattle for Milk Production: Achievements, Challenges and Opportunities in India-A Review. Advances in Dairy Research 4(3), 158.

Verma, M.K., Sachdeva, G.K., Yadav, A.K., Gautam, S., Ali, M.M., Bindal, S., 2016. Effect of genetic and non-genetic factors on milk yield and milk constituents on Sahiwal cattle. Indian Journal of Animal Research 50, 808-810.

Wakchaure, R., Ganguly, S., Ahmad, P., Kumar, P., Kumar, A., Sharma, S., 2015. Development of Crossbred Cattle in India: A Review. International Journal of Emerging Technology and Advanced Engineering 5(10), 169-183

Wilson, T., Crandall, C., 2010. Effect of thermal stress on cardiac function. Exercise and Sport Sciences Reviews 39(1), 12-17.

Young, J.C., Moarefi, I., Hartl, F.U., 2001. Hsp90: A specialized but essential protein-folding tool. The Journal of cell biology 154(2), 267-273. 